\title{
Critical Literacy \& Critically Reflective Writing: Navigating Gender \& Sexual Diversity
}

\begin{tabular}{|r|l|}
\hline Journal: & English Teaching: Practice and Critique \\
\hline Manuscript ID & ETPC-09-2018-0082.R2 \\
\hline Manuscript Type: & Research Article \\
\hline Keywords: & Critical literacy, Reflective writing, gender and sexual diversity \\
\hline \multicolumn{2}{|l}{} \\
\hline
\end{tabular}

\section{SCHOLARONE \\ Manuscripts}




\title{
Critical Literacy \& Critically Reflective Writing: Navigating Gender \& Sexual Diversity
}

\begin{abstract}
In this article, I draw on Janks' territory beyond reason as well as literature on (critically) reflective writing to explore how a space for personal, affective writing in the classroom might enable teachers, students and learners to 1) come to terms with gender as a social practice, 2) locate themselves in the relations of power, marginalisation and subversion being explored, and 3) negotiate the internal contradictions that come with personal and social transformation. The author presents and unpacks how 2nd-year undergraduate Bachelor of Education (B.Ed.) students at a prominent university in Johannesburg, South Africa, unpacked issues of gender and sexual diversity in a critical literacy course. This article focuses on students' completion of a reflective writing task but is situated in a broader study on critical literacy and gender and sexual diversity. The findings suggest the need for sustained critically reflective writing in the classroom and continued research in critical literacy as both a rationalist and affective project. Furthermore, the findings suggest ways in which critically reflective writing was used to create a space where students could place themselves into the content and relations of power being studied and identify and unpack the ways in which discourses of power have informed their own identities over time, with the intent to develop the capacity to position themselves in more socially conscious ways. This study therefore illustrates only a fraction of how students might use reflective writing to come to terms with controversial topics, place themselves in the systems of power, marginalisation or subversion being explored, and negotiate the internal contradictions of transformation. However, the data also suggests that there is potential for this practice to have a greater role in classroom practice, a deeper effect on learners' understanding of self and society, and further research on the impact of critical reflection in the classroom.
\end{abstract}

\section{Key words:}

Critical literacy, reflective writing, gender and sexual diversity 


\section{Introduction}

Where identification promises the fulfilment of desire, reason cannot compete. (Janks, 2002, 10).

Janks' (2002) words in the article Critical Literacy: Beyond Reason serves as the basis for the argument I make here: that the role of self (in relation to identity, place, politics and desire) is, for its part, a vital component for critical literacy practice. While Janks (2002) explores this in relation to textual analysis and students' investment in particular social issues, I aim to consider how space for students' personal reflections might enable them to make the critical turn of placing themselves in, around or outside the relations of power explored in critical literacy classrooms.

This is particularly important if the people in critical literacy classrooms are to address controversial relations of power and identity such as those related to gender and sexual diversity. For example, in South Africa the belief that homosexuality is unAfrican still persists in everyday discourses (Bhana, 2013; Jagessar \& Msibi, 2015) and affects how both hegemonic and marginalised ways of doing gender and sexuality are policed. How, then, when issues are naturalised in ways of speaking, thinking, doing and believing (Gee, 2008) do teachers and students explore them in constructive and critical ways? This is particularly pertinent where gender performance and sexual identity are conventionally conflated (Butler, 1993 and 2006) and used to justify heterosexism, bullying, and violence (from the symbolic to the physical). Therefore, I propose the need for critical literacy classrooms to explore power in relation to self: how does one position oneself in relation to privilege and subordination in the process of reimagining society and social justice?

In this study and the course that it investigates, I draw on conceptions of gender as a social practice, the performance of which is socio-culturally situated (Butler, 2006), as well as notions of sexual identity as an invisible difference that is intrinsically connected to issues of personal and social power (Butler, 2006). Reading and writing identity, then, serve as critical literacy practices where identity construction and performance can be interrogated through critical reflection.

To explore this, I present and unpack how $2^{\text {nd }}$-year undergraduate Bachelor of Education (B.Ed.) students at a prominent university in Johannesburg, South Africa, reflected on their own experiences with gender and sexual diversity in writing. The students discussed here attended a module on critical literacy as part of their English (sub)major. The module was the site of a broader research project that explored critical literacy as a means to engage with gender and sexual diversity in South African English classrooms (Govender, 2017, 2018 
$\& 2019)$. The reflective writing activity constituted one small part of that pedagogy where students constructed short, autobiographical vignettes. An analysis of these vignettes offers possibilities for critically reflective writing to be used as a space where students identify and unpack how discourses of power have positioned their own identities and develop the capacity to position themselves in more socially conscious ways.

\section{Reason, Desire \& Reflective Writing in the Critical Literacy Classroom}

Despite critical literacy's socially transformative agenda, it is entirely possible that "students could produce the required deconstructive reading of the text... without any change in either their aspirations or their practices" (Janks, 2002, 10). As such, there is always the risk that power can be addressed in only superficial ways in the classroom, despite the intentions of the teacher. Janks (2002) found that it was not easy to predict which texts for analysis students would react to and in what ways, because of the "territory beyond reason" (Janks, 2002, 9).

This 'territory' includes the politics of desire and identification where a purely rationalist approach to teaching about and through social issues must consider students' emotional connections to the social issue itself. That is, it is perhaps easier for students who identify with positions of resistance if they themselves have been marginalised in some way. On the other hand, students who identify with normativity may struggle - or find it impossible - to see how that norm marginalises others, or how they have been positioned by that norm. Zembylas $(2008,65)$ recognises this ability to see one's own privilege as necessary for critically reflexive work that is considerate of emotional attachment and so consists in the ability to question emotionally charged, cherished beliefs exposing how privileged positions and comfort zones inform the ways in which one recognises what and how he or she has been taught to see or act (or not see/act), and empowering different ways of being with or for the other.

Perhaps it is also more complex than this: students who occupy a marginalised position in relation to socio-economic circumstance may see their plight as being more significant over those who suffer discrimination and subordination due to their gender and/or sexual identities. At any given point, one may occupy a position of privilege, marginality, or invisibility depending on the identity category or social issue being highlighted.

In situations where issues of gender and sexual diversity are concerned, emotional responses and attachments to ideologies can enable or inhibit productive ways of imagining 
more socially just futures. Ellsworth (discussed in McKinney, 2008) suggests that, in such cases and perhaps for all critical literacy practice, an assumption that students will automatically be taken up by critical practice and transform themselves and society "ignores the way in which people have investments in particular social positions and discourses, and that these kinds of investments are not lightly given up" (McKinney, 2008, 100). Perhaps, then, both positions of privilege and marginalisation, across a spectrum of identities and social issues, needs to be interrogated.

As one option, reflective writing may provide a space for students to explore a social issue in relation to their own histories, geographies, religions/traditions, ideologies, and life experiences. In this sense, reflection is "active, persistent, and careful consideration of any belief or supposed form of knowledge in the light of the grounds that support it and the further conclusions to which it tends" (Dewey, 1933, 9), in conjunction with a Freirean understanding that "Liberation is a praxis: the action and reflection of men and women upon their world in order to transform it" (Freire, 1970, 52). Here, according to Freire (1970), humility in recognising one's own place in the socio-political orders of oppression is fundamental to transformation. By looking at critical incidents and experiences (as texts) in relation to issues of power, teachers and students might interrogate the ways in which social and political power influence the everyday construction of individual identities, how individuals take up or resist hegemonic orders and the ways in which individuals occupy positions of privilege and subordination at different times and in different spaces.

In the classroom, 'authentic reflection' trusts that students and teachers, over time, can make connections between systems of power and themselves before endeavouring to dismantle those hegemonies, de/reconstruct their own subject positions, and explore ways to realise imagined change (Vittoria, 2018; Ryan \& Ryan, 2013; Janks, Rogers \& O’Daniels, 2017). By asking students to engage with personal critical incidents from everyday experiences, they might tap into the ways in which they have been positioned willingly and unwillingly, knowingly or unknowingly, by the dominant discourses of their time.

Confronting one's own privilege and subordination, as well as the privileging or subordination of others, is not an easy task. Ryan and Ryan (2018) propose a useful way of thinking about how to collate the various approaches of reflectivity into a model for doing and measuring critical reflection. It therefore becomes useful to quote at length their explanation:

Such reflection is underpinned by a transformative approach to learning that sees the pedagogical process as one of knowledge transformation rather than 
knowledge transmission (Kalantzis \& Cope, 2008; Leonardo, 2004). The learner is an active participant in improving learning and professional practice. Critical social theory underpins this transformative approach to reflection [and is] concerned with emancipation; however it also engages in a language of transcendence, whereby critique serves to cultivate students' abilities to question, deconstruct and reconstruct their own practices and imagine an alternative reality (Giroux, 1988; Kincheloe, 2003). When students are provided with opportunities to examine and reflect upon their beliefs, philosophies and practices, they are more likely to see themselves as active change agents and lifelong learners within their professions (Mezirow, 2006) (original parenthesis: Ryan \& Ryan, 2018, 246)

Writing, interspersed throughout other classroom practices, might help to create a continuous safe space for students to tackle issues of power and society in a personal way. Emotion, in this space, would be a resource rather than a hinderance to criticality. Furthermore, ongoing reflective writing can be challenged: 1) using Kalantzis and Cope's (2008) taxonomy of experiencing, conceptualising, analysing and applying to measure critical engagement, and 2) moving from simulated to real scenarios to measure development in reflective practice (Ryan \& Ryan, 2018).

Critical reflection in this sense is about making the commonsense strange (Janks, 2010; Freire, 1970; Freire \& Macedo, 1987): across personal, public and political spheres. By doing so, students can attempt to re-evaluate self and society, imagining transformation as both personal and Political (Janks, 2010).

\section{Methodology}

The data presented here was collected during the implementations of a critical literacy module for second-year B.Ed. students at a university in Johannesburg, South Africa. This course explored critical literacy by unpacking the relationship between language, literacy and power for secondary school classrooms using gender and sexual diversity as the example social issue.

\section{The module}

The module comprised of 9 seminars and worked from a workbook that I had designed which included a range of topics and activities for engaging with gender and sexual diversity in secondary English language and literacy classrooms. Namely, these topics included 
Language, Policing \& Subversion, (Re)Design, and Social Impact (Govender, 2018): 1. Language, involves students discussing how language can be used to name people and activities in ways that (de)legitimise particular identities and practices across modes and media. 2. Policing \& Subversion explored a variety of texts that represented 'alternative' ways of being or doing sex, gender and sexuality, as well as an analysis of the kinds of responses that these representations received. This section included navigating representations of both hegemonic and subversive gender and sexual identities and practices as a means to unpack how powerful discourses emerge and how resistance takes form. 3. (Re)Design drew on New London Group's (1996) concept of design as transformative practice. Reflecting on the subversive texts that students had analysed, strategies for reconstructing representations of gender and sexual diversity in classrooms were explored. Finally, 4. Social Impact introduced students to ways of thinking about the social effects that their pedagogical decisions in the classroom might have in maintaining, reproducing or challenging social norms. A deeper analysis of the student teachers' responses to the course content and up-take of critical literacy practice can be read found in Lopez-Gopar's (2019) International Perspectives on Critical Pedagogies in ELT.

In the broader study, a qualitative mixed methods approach was adopted for the collection and analysis of data including field notes of the classes I taught, critically reflexive accounts of the design process of the workbook and other materials or resources used for teaching the module (see Govender, 2018), a 'research journal' in which I recorded my own responses and reflections on interactions with students throughout the study (see Govender, 2017), notebooks wherein students who attended the module completed activities both in and out of the lecture theatre, students' evaluations of the module content and presentation, as well as the final assessment task where students produced their own critical literacy materials (see Govender, 2019).

What sets this apart from other research in Initial Teacher Education (ITE) is the compulsory nature of the module - all students registered for English II were required to attend the critical literacy module as part of their degree. While participation in the research was voluntary, the module itself was not an elective. This meant that the cohort of students were diverse and the selection of participants in the research project included, along a spectrum of investments (Darvin \& Norton, 2015), students who were interested in gender and sexual diversity and those students who were explicitly uncomfortable with the topic. 
For this article, I draw on the data collected from only one section on Language \& Policing (see above). The data set from this section includes the reflective writing produced by 6 students, as a voluntary homework task. As this task was not formally assessed and the module did not require any participants (lecturer/researcher or students) to claim their own gendered or sexual identities in any form, students could choose to complete in the task or not. Ethical approval was obtained for the study and participants consented to the use of the data for research.

In the lecture, Robert Hamblin's (in Morgan, Marais \& Wellbeloved, 2009) autobiographical poem about being a transgender man was analysed and discussed. Using this as a springboard, students were asked to reflect on a moment when they think they were socialised into a particular gender order.

The vignettes were analysed using Fairclough's (2001) model of Critical Discourse Analysis (CDA), firstly, to reveal patterns across the data set (themes 1 and 2), and secondly to uncover how students reflected on their own identities in relation to diversity (theme 3 ). The critical analysis spans Fairclough's (2001) domains of description, interpretation and explanation in order to draw meaning from the written data and explore the socio-cultural significance of those meanings.

\section{Data presentation \& analysis}

The data presented and analysed here reveals three major themes: (1) gender as a social practice, (2) gender as intersectional, and (3) critical internal contradictions. The discussion of themes 1 and 2 outline the patterned meanings and implications in students' writing, while theme 3 presents an analysis of two particular examples of writing that engage with sexual identity. In each case, I draw on the data to evidence the themes and use Fairclough's (2001) model for critical discourse analysis to explore how students' reflective writing illustrates their positions in relation to the course content (Ryan \& Ryan, 2013) as well as consider what their writing reveals about learning through a critical literacy approach.

\section{(1) Gender as a social practice}

While students' written reflections on gender policing in their own lives varied in length and content, they all presented a definite theme that gender is a social practice. This mirrors Connell's (1995) work on hegemonic masculinities and other studies that see gender practice and performance as socio-culturally situated and regulated (Francis, 2017; Paechter, 1998 \& 2006; Butler, 1993 \& 2006; Connell, 1995 \& 2000; Gevisser \& Cameron, 1994; Luyt, 2012; 
Rich, 1993; Tucker, 2009). Recognition of this is significant because it contradicts the commonsense sex-gender-sexuality relation as a necessary one (Butler, 2006).

The following extracts are quoted directly from each of the written reflections, and refer explicitly to gender being a process of socialisation:

"I grew up and was socialised to respond and maintain characteristics of a girl" (A12.5);

"I became socialised into a gender category through religion" (A01.5);

"I was raised to be a respectful young lady. I had to behave like a girl..." (A03.5);

"'Proper' gender is falling into a category of either male + masculine or female + feminine created by societies" (A02.6);

"When you grow up, you are also obliged to attend an initiation school for two months being taught on how to behave like a man" (B01.10); and

"In my religion Islam teaches us ladies to be modest + conservative in our dressing" (A14.4).

From the extracts above, it is easy to see how these students were able to locate some of the ways that they learnt, or acquired, particular gender performances. From the role of religion and initiation schools to families, the extracts exemplify a kind of positioning of oneself in the theory. Students began to engage not only with memory as meaning, but also as situated in particular socio-cultural conditions (Fairclough, 2001). Not only does this suggest that identification (locating oneself in the content of the classroom) takes place but also application (using the content of the classroom to reconsider one's own experiences) as part of the (re)learning process in a transformative pedagogy. Students located the course content, themselves, and the embedded ideologies that inform their experiences as "real, socially operative [sites] of institutional and societal processes of struggle" (Fairclough, 2001, 117) and this is evident in the way they position their experiences with gender in processes of being "taught", as well as being "socialised" and "raised" into gender roles. In these utterances alone is the notion of gender order as systemic, and individual agency as minimal. Both the processes and sites of struggle also matter. For example, the differences between how a particular kind of masculinity was learnt by the participant who wrote about attending a Southern African initiation school may resonate and differ in many ways from the participant whose affiliation with Islam created a space for learning 'proper' femininities. The particular experiences and conditions of gender identity construction (that is, how the rules for doing gender were learnt) suggest that the personal spaces of participants' lives could be highlighted as significant sites of critical reflection. Over time, it is suggested that such critical reflection must become more rigorous (Ryan \& Ryan, 2013) in order to be, one, 
more cognitively challenging for these students as future teachers and reflective practitioners, and two, to enable a deeper sense of consciousness of the relationship between self, word, action and social effect (Vittoria, 2018). For instance, evaluating how students seem to place themselves in object-position (as in Halliday's, 1985, done-tos) in their own writing might reveal more about how they perceive their own agency.

The application, negotiation and exploration of the content in relation to one's own lived experiences "brings high level academic understandings together with students' lived experience and provides them with the intellectual means for complex analyses" (Comber, 2015, 365). The reflective writing space is a fluid one and so the meanings that students produce here is not yet fixed, but perhaps allows students to anchor conceptual knowledge in their known realities in the process of making meaning (Smagorinsky, 2001).

This is particularly significant when handling content that is sensitive or controversial to so many. In trying to conceptualise gender as a social practice, established understandings of gender conflated with biological sex need to be deconstructed, unlearned and renegotiated with nondominant perspectives (Govender, 2019). This is not an easy task. Merely introducing texts with same-sex couples or nonconforming gender and sexual identities does not automatically ensure that students, teachers and school curriculums are transformed (Kumashiro, 2000). In contexts where hegemonic gender order is still heterosexist and cisnormative, finding ways for students to negotiate meaning and come to terms with diverse perspectives is necessary to foster a constructive turn toward socially just pedagogies.

But, gender does not exist on its own. As illustrated in students' vignettes, what it means to learn, acquire and become a gender identity is deeply connected with the place, time, culture, language, age, among others, that situate each individual and their actual or imagined communities.

\section{(2) Gender as intersectional}

In the same way that Gevisser and Cameron (1994) emphasise that there is no one gay identity in South Africa, there is also no single, essentialised identity for gender, race, culture/tradition, religion, and so on, (Connell, 1995; Milani, 2013; Ritchie, 2010). The students in this study draw on a myriad of experiences that inform and are informed by their own gendered identities. The following table briefly outlines these intersections in students' writing:

Table 1: Intersections with Gender 
From home to broader society, to the recognition that gender and sexuality are issues around the "real world" (A14.4), it is their everyday spaces and interactions that these students come to know and live gendered identities. That is, whether these students consciously recognise it or not "[s]pace can be filled with all kinds of social, cultural, epistemic, and affective attributes. [That] then becomes 'place', a particular space in which senses of belonging, property rights, and authority can be projected" (Blommaert, 2005, 222 in Milani, 2013, 206207). Here, belonging, or not belonging, and the relations of power that exist within these spaces seemingly inform how students have considered gender and sexuality.

From the figures in Table 1, the local and lived spaces of daily life are the ones most prominent for being socialised into hegemonic gender order. It is the life-long, cumulative engagement with these interactions, in everyday spaces, that ways of being, acting, speaking, and understanding are subjected to relationships of power and attached to ideas about morality. It is also within many of these spaces that gender intersects with the other attributes of identity, like race, religion, language, or sexuality.

In this particular data set, only one reference is made to ethnicity, "I am an Indian", with a corresponding declaration of religious identity: "I am a Muslim. I am an Indian”. After these statements, this student focuses on religious identity, social spaces and gender construction. This can be seen in the way that the student has written about their understanding of the male-female binary and its associated gender roles:

“...in our culture men are given the status of superiority... Breadwinners, Money makers. Women are looked at as housewives + mommies. It's questioned when mom's rake in the money" (extract from A14.4).

It is uncertain whether 'culture' here is used to refer to Islamic culture, the Islamic religion or an Indian culture, however it is through all of these social institutions that the sexes and their 'appropriate' gender roles and performances are constructed. Heteronormative cisgender roles are rationalised as intrinsic to 'culture'. Religion and culture/tradition are regularly foregrounded as institutions that regulate gender construction and performance in this data set. In each of the vignettes, there is some reference to at least one of these social institutions. Each reference to religion, culture or tradition, however, is still compounded by an intersection with age and gendered social roles:

"Kneeling was expected of a girl in my culture especially when serving adults" (A12.5);

"Due to my culture and religion, once you've become matured, there are certain things that become compulsory to do on a daily basis and the manner in which it is done is different for males and females" (A01.5). 
Or it was compounded by an intersection with language, where language reinforces sexed, gendered or sexualised difference as intrinsic to identity:

" $[\mathrm{I}] \mathrm{n}$ my culture there are many words that have separate words for male $\&$ female. e.g. in the Arabic language the "Hu" at the end of an object is for males and the letter "Haa" is for females" (parenthesis added: A01.5);

“'Because you are a girl'. One phrase I have heard and hated my entire life" (A02.6). And, in some cases it is even compounded by painful intersections with the conflict between family expectations and personal aspiration:

After my mother died, my step dad expected me to cook and clean whilst my studies were sidelined. I will never hate anything as much as I hate this period of my life where I have to cook, clean and be subservient to a man because I am a young woman (extract from A02.6).

These institutionalised normative gender roles seem to bind almost all intersections of gender with other identity categories and suggests that these students' experiences resonate with research on gender and sexual diversity in South Africa (Lock Swarr, 2009; Bhana, 2013 Mayeza, 2017; Francis, 2017; Francis \& Reygan, 2016; and so on). If such normativity persists in the lives of student teachers, surely it becomes necessary for (teacher) education at large to intervene? Critical reflective writing, as one practice in a broader critical literacy approach, may provide a way for teachers and learners to navigate identity, power and diversity in meaningful and constructive ways, where "processes of self-reflection in teacher education require teachers to interrogate their experiences of marginalisation and privilege" (Reygan, 2019) by asking critical questions (Janks, 2010) of themselves.

In each case, these students have engaged with a critical reflection of their own lives and the social structures that have come to influence their identities. Perhaps, then, part of taking the critical turn means consciously exploring how one has been positioned by their sociocultural context (Fairclough, 2001), making texts of themselves. Only then can one begin to resist or choose to take up the positions available in that context, using literacy "to raise consciousness (conscientizacao) regarding the actual reality of oppression" (Vittoria, 2018, 38).

\section{(3) Reflecting on Sexuality \& Sexual Diversity}

Work on the pedagogies that enable students and teachers to explore, understand and negotiate issues of self and power through language has become especially important for understanding how education can work in relation to issues of sexuality. This is where 
nondominant sexualities are still avoided because they seem too controversial to discuss with school-going students or where teachers feel ill-equipped to engage with such topics (Francis \& Reygan, 2016; Reygan, 2019; Francis, 2012).

In this section, I discuss two examples: students A and B. While student A identifies as 'unsure' about their sexual identity, student B implies a heterosexual identity. By discussing these two examples, it becomes evident that a wide spectrum of viewpoints and experiences can occupy a single learning space, reinforcing critically reflective writing as a way for individuals to process their relationship with curricular content and diversity.

For student A, a queer understanding of sexuality is taken: Being 'unsure' about sexual identity suggests that sexuality itself is recognised as fluid. Furthermore, this student states that their sexuality is assumed to be heterosexual, recognising the heteronormative context they find themselves in. Their expression can be read as a resistance to such heteronormativity where the student was able to name their experience without conflict (Pennell, 2019). This practice of naming and renaming oneself and the world signifies a potential for increased agency (Freire, 1970) where learners and teachers who occupy gender and sexual diversity can claim their experiences and critically reflect on them in a move toward personal and social transformation.

However, this was not always the case. While critical literacy may open spaces for resistance, it may also be a space for contradiction. Student B who implicitly self-identifies as a heterosexual also positions themselves as both conservative, because of their Islamic and Indian identities, and liberal by aligning themselves to the idea of freedom. In this sense, critical literacy helped reveal the internal conflicts and contradictions that come with transformation.

Initially, an inclusive, liberal discourse, was used to validate sexual diversity:

"In the real world there is a variety of sexuality - Gays, lesbians, bisexuals" (extract from A14.4).

However, this was followed by their personal feelings toward sexual diversity::

"Do I believe in all? Maybe not... Actually no!" (A14.4).

There is recognition that sexual diversity exists, while there is disagreement that nonheterosexual identities are 'right'. This may be an example of hyperinclusivity that masks internal resistance to types of diversity (Govender, 2019). However, this student thereafter reverts to the liberal discourses of freedom which is only problematic because their use of 'freedom' is expressed as 'freedom of choice': 
"The world is changing so is society. People are free \& open to choose his/her sexuality" (A14.4); and

"The world is free. Sexuality is your choice!" (A14.4).

Again, the stereotype that non-heterosexual identities are a 'lifestyle choice' is maintained. This reproduces the discourses of heteronormativity despite its appearance of being inclusive through the use of words such as "free", "open", or "choice" juxtaposed against the illegitimating declaration that not "believe[ing] in all" is still present. For the critical literacy classroom, this way of speaking about difference and the kind of hedging used is a useful text for deconstructing the nuances of power and language.

Looking at the policing of gender in relation to the lives of students has thus been helpful for considering students' own positions in relation to gender and sexual diversity, whether they themselves fit typically normative or nonconforming identities. A prolonged practice of critical reflective writing is therefore recommended to further deepen both personal and social consciousness; a fitting practice for the critical literacy classroom.

\section{Conclusion}

If critical literacy is to equip teachers with the capacity to confront and transform discourses in and out of schools, then practices that purposefully engage with uncomfortable positions is needed. As such education beyond rationality or formulaic reasoning is necessary when using the classroom as a medium for addressing social issues that are often bound to emotive responses. Issues related to gender and sexual diversity, for instance, can tug at often hegemonic lines of reasoning that are informed by faith, heterosexist normativity, patriarchal traditions, a history of symbolic and real violence, as well as the very systems of government or social order under which people live. Even in the seemingly small declarations of "no!" or the positioning of oneself as a victim of systemic gender order through word-order and sentence structure, space for taking up and resisting power can be realised. In situations such as these, it is very easy for social justice work to be read as a threat to normativity rather than a move toward equity.

Existing resources on critically reflective writing are vital for imagining what this prolonged practice might look like in classrooms. As discussed, Ryan and Ryan (2013) provide a framework for considering how critical reflectivity can be practised and measured in higher education. For teacher education that seeks to equip new and developing teachers with the capacity to confront issues of diversity, especially through a critical literacy project, this criteria-based and developmental framework could prove useful. Numerous other sources 
are cited in this work as well (including Barney \& Mackinlay, 2010; Carrington \& Selva, 2010; and Ovens \& Tinning, 2009). Similarly, Liu (2015) recommends that not only should the what of reflective practice be considered, but also the how and the why. By doing so, student teachers might begin to ask questions about how their reflections become critical or limiting, as well as why their reflections may or may not have an impact on their own teaching and learning. While Liu (2015) does not deal with any specific social issue, the framework serves as a useful base from which to consider ways of doing critical reflection and how this might be implemented through continuous writing practice. Furthermore, Pennell's (2019) extended metaphor of kayaking for thinking about literacy and numeracy teaching/learning is another example of anti-oppressive pedagogies. Pennell (2019) reiterates, as eddies in a river, the need for measured and continued practices of reflection which could be anchored in practices of writing.

Specific research in gender and sexual diversity in South Africa also suggests the need to include the affective when addressing issues that are deemed contentious for students and teachers (Reygan, 2019; Francis, 2017). Similarly, Banegas, Jacovkis and Romiti (2019) find a place for reflective practice in arguing for the relevance of gender and sexual diversity in TESOL initial English language teacher education in Argentina. Perhaps there is scope for further, long-term research in the role of critically reflective writing, critical literacy classrooms and the territory beyond reason across social issues and educational contexts.

Throughout this article, I have used critically reflective writing to argue for the inclusion of personal, emotive and authentic engagement with social issues as part of everyday classroom practice for critical literacy teachers and learners. The data presented here is limited and illustrates only a fraction of how students might use reflective writing to come to terms with controversial topics, place themselves in and out of systems of power, marginalisation, or subversion, and negotiate the internal contradictions of transformation. However, this data also suggests that there is potential for this practice to have a greater role in classroom practice, a deeper effect on learners' understanding of self and society, and further research on the impact of critically reflective writing in the classroom. Perhaps a sustained practice of critically reflective writing is what is needed, as well as processes of self and peer evaluations that put that writing up for critical analysis. 


\section{References}

Banegas, D. L., Jacovkis, L. G. \& Romiti, A. (2019). A Gender Perspective in Initial English Language Teacher Education: An Argentinian Experience. Sexuality \& Culture. Springer. https:/doi.org/10.1007/s12119-019-09604-8

Barney, K., \& Mackinlay, E. (2010). Creating rainbows from words and transforming understandings: Enhancing student learning through reflective writing in an Aboriginal music course. Teaching in Higher Education, 15(2), 161-173.

Bhana, D. (2013). Parental Views of Morality \& Sexuality \& the Implications for South African Moral Education. Journal of Moral Education, 42(1), 114-128.

Butler, J. (1993). Imitation \& Gender Insubordination. In H. Abelove, M. Aina Barale \& D. M. Halperin (eds.) The Lesbian \& Gay Studies Reader. Routledge: New York \& London.

Butler, J. (2006). Gender Trouble. Routledge: New York.

Carrington, S., \& Selva, G. (2010). Critical social theory and transformative learning:

Evidence in pre-service teachers' service-learning reflection logs. Higher Education Research \& Development, 29(1), 45-57.

Comber, B. (2015). Critical Literacy \& Social Justice. Journal of Adolescent \& Adult Literacy, 58(5), 362-367.

Connell, R. W. (1995). Masculinities. Allen \& Unwin: Australia.

Connell, R. W. (2000). The Men \& the Boys. Allen \& Unwin: Australia.

Darvin, R. \& Norton, B. (2015). Identity \& a Model of Investment in Applied Linguistics. Annual Review of Applied Linguistics, 35(1), 36-56.

Dewey, J. (1933). How we think: A Restatement of the relation of Reflective Thinking to the Educative Process. D.C. Heath: Boston.

Fairclough, N. (2001). Language \& Power. Second Edition. Longman: London

Francis, D. (2012). Teacher Positioning on the Teaching of Sexual Diversity in South African Schools. Culture, Health \& Sexuality, 14(6), 597-611.

Francis, D. (2017). Homophobia \& Sexuality Diversity in South African Schools: A Review. Journal of LGBT Youth, 14(4), 359-379.

Francis, D. \& Reygan, F. (2016). 'Let's see if it won't go away by itself': LGBT Microaggressions among Teachers in South Africa. Education as Change, 20(3), 180201.

Freire, P. (1970). Pedagogy of the Oppressed. M. Bergman Ramos (trans. 1970). Continuum: New York. 
Freire, P. \& Macedo, D. (1987). Rethinking Literacy: A Dialogue. P. Freire \& D. Macedo (eds.) Literacy: Reading the Word \& the World. Bergin \& Garvey: New York.

Gee, J. P. (2008). Social Linguistics \& Literacies. Routledge: London \& New York.

Gevisser, M. \& Cameron, E. (1994). Defiant Desire. Ravan Press: Johannesburg, South Africa.

Govender, N. N. (2017). The Pedagogy of 'Coming Out': Teacher Identity in a Critical Literacy Course. South African Review of Sociology, 48(1), 19-41.

Govender, N. N. (2018). Deconstructing Heteronormativity \& Hegemonic Gender Orders through Critical Literacy \& Materials Design: A Case in a South African School of Education. In E. Walton \& R. Osman (eds.) Teacher Education for Diversity: Conversations from the Global South. Routledge: London \& New York. P. 36-52. Govender, N. N. (2019). Negotiating Gender \& Sexual Diversity in English Language Teaching: 'Critical'-Orientated Educational Materials Designed by Pre-Service English Teachers at a South African University. In E. López-Gopar (ed.) International Perspectives on Critical Pedagogies in English Language Teaching. Palgrave Macmillan: Cham, Switzerland. P. 125-149.

Halliday, M. A. K. (1985). An Introduction to Functional Grammar. London, New York, Melbourne \& Auckland: Edward Arnold.

Jagessar, V. \& Msibi, T. (2015). "It's not that bad": Homophobia in the Residences of a University in KwaZulu-Natal, Durban, South Africa. Agenda, 29(1), 63-73.

Janks, H. (2002). Critical Literacy: Beyond Reason. The Australian Educational Researcher, 29(1), 7-26.

Janks, H. (2010). Literacy \& Power. Routledge: New York \& London.

Janks, H., Rogers, R. \& O’Daniels, K. (2017). Language \& Power in the Classroom. In T. L. McCarty \& S. May (eds.) Language Policy \& Political Issues in Education. Springer: New York. P. 185-197.

Kalantzis, M., \& Cope, B. (2008). New learning: Elements of a science of education. Cambridge: Cambridge University Press.

Kumashiro, K. (2002). Troubling Education: Queer Activism and Antioppressive Pedagogy. Routledge Falmer: New York and London.

Liu, K. (2015). Critical Reflection as a Framework for Transformative Learning in Teacher Education. Educational Review, 67(2), 135-157.

Lock Swarr, A. (2009). "Stabane”, Intersexuality, \& Same-Sex Relationships in South Africa. Feminist Studies, 35(3), 524-548. 
López-Gopar, E. (ed.) (2019). International Perspectives on Critical Pedagogies in English Language Teaching. Palgrave Macmillan: Cham, Switzerland.

Luyt, R. (2012). Constructing Hegemonic Masculinities in South Africa: The Discourse \& Rhetoric of Heteronormativity. Gender \& Language, 6(1), 47-77.

Mayeza, E. (2017). 'Girls don't play soccer': Children Policing Gender on the Playground in a Township Primary School in South Africa. Gender \& Education, 29(4), 476-494.

McKinney, C. (2008). Uncomfortable Positionings: Critical Literacy \& Identity in a PostApartheid University Classroom. K. Cooper \& E. R. White (eds.) Critical Literacies in Action: Social Perspectives \& Teaching Practices. Sense Publishers: Rotterdam, Netherlands. P. 99-116.

Milani, T. M. (2013). Expanding the Queer Linguistic Scene: Multimodality, Space \& Sexuality at a South African University. Journal of Language \& Sexuality, 2(2), 206234.

Morgan, R., Marais, C. and Wellbeloved, J. R. (eds.) (2009). Trans: Transgender Life Stories from South Africa. GALA: South Africa.

New London Group. (1996). A Pedagogy of Multiliteracies: Designing Social Futures. Harvard Educational Review, 66, 60-92.

Ovens, A., \& Tinning, R. (2009). Reflection as situated practice: A memory-work study of lived experience in teacher education. Teaching and Teacher Education, 25(8), 11251131.

Paechter, C. (1998). Educating the Other: Gender, Power \& Schooling. Falmer Press: London, United Kingdom.

Paechter, C. (2006). Masculine Femininities/ Feminine Masculinities: Power, Identities \& Gender. Gender \& Education, 18(3), 235-263.

Pennell, S. M. (2019). Moments of Active Reflection: Eddies. In S. M. Pennell. Queering Critical Literacy \& Numeracy for Social Justice: Navigating the Course. Palgrave Macmillan: Cham. P. 73-88.

Reygan, F. (2019). Sexual \& Gender Diversity in Schools: Belonging, In/Exclusion \& the African Child. Perspectives in Education, 36(2), 90-102.

Rich, A. (1993). Compulsory Heterosexuality \& Lesbian Existence. In H. Abelove, M. Aina Barale \& D. M. Halperin (eds.) The Lesbian \& Gay Studies Reader. Routledge: New York \& London.

Ritchie, J. (2010). How Do You Say "Come Out of the Closet” in Arabic? Queer Activism and the Politics of visibility in Israel-Palestine. In $G L Q, 16(4), 557-575$. 
Ryan, M. \& Ryan, M. (2013). Theorising a Model for Teaching \& Assessing Reflective Learning in Higher Education. Higher Education Research \& Development, 32(2), 244-257.

Smagorinsky, P. (2001). If Meaning Is Constructed, What Is It Made From? Toward a Cultural Theory of Reading. Review of Educational Research, 71(1), 133-169.

Tucker, A. (2009). Queer Visibilities: Space, Identity \& Interaction in Cape Town. WileyBlackwell: Sussex, United Kingdom.

Vittoria, P. (2018). Critical Education in Paolo Freire: Educational Action for Social Transformation. Journal of Phenomenology \& Education, 22(51), 37-44.

Zembylas, M. (2008). Engaging with Issues of Cultural Diversity \& Discrimination through Critical Emotional Reflexivity in Online Learning. Adult Education Quarterly, 59(1), $61-82$. 


\section{Critical Literacy \& Critically Reflective Writing: Navigating Gender \&}

\section{Sexual Diversity}

\section{Summary of minor revisions}

The following table outlines the general responses to the reviewers' comments. Detailed changes to the article have been tracked throughout in red.

\begin{tabular}{|c|c|}
\hline \multicolumn{2}{|c|}{ Revision Two: Minor revisions } \\
\hline $\begin{array}{l}\text { Reviewer } \\
\text { comment/change item }\end{array}$ & Revised wording \\
\hline $\begin{array}{l}\text { Presentation of data: } \\
\text { revise use of bullet } \\
\text { points }\end{array}$ & $\begin{array}{l}\text { Bullet points were removed for a more fluid structure and reading path. } \\
\text { Furthermore, the data was used where relevant in the existing discussions } \\
\text { to increase its impact on the reader. For example: } \\
\text { 1. Under heading (1) Gender as a social practice } \\
\text { Students located the course content, themselves, and the embedded } \\
\text { ideologies that inform their experiences as "real, socially operative } \\
\text { [sites] of institutional and societal processes of struggle" (Fairclough, } \\
\text { 2001, 117) and this is evident in the way they position their } \\
\text { experiences with gender in processes of being "taught", as well as } \\
\text { being "socialised" and "raised" into gender roles. In these utterances } \\
\text { alone is the notion of gender order as systemic, and individual agency } \\
\text { as minimal. } \\
\text { For instance, evaluating how students seem to place themselves in } \\
\text { object-position (as in Halliday's, 1985, done-tos) in their own writing } \\
\text { might reveal more about how they perceive their own agency. } \\
\text { 2. Under heading (3) Reflecting on sexuality and sexual diversity } \\
\text { This reproduces the discourses of heteronormativity despite its } \\
\text { appearance of being inclusive through the use of words such as } \\
\text { "free", "open", or "choice" juxtaposed against the illegitimating } \\
\text { declaration that not "believe[ing] in all" is still present. } \\
\text { 3. Under heading Conclusion } \\
\text { Issues related to gender and sexual diversity, for instance, can tug at } \\
\text { often hegemonic lines of reasoning that are informed by faith, } \\
\text { heterosexist normativity, patriarchal traditions, a history of symbolic } \\
\text { and real violence, as well as the very systems of government or social } \\
\text { order under which people live. Even in the seemingly small } \\
\text { declarations of "no!" or the positioning of oneself as a victim of } \\
\text { systemic gender order through word-order and sentence structure, } \\
\text { space for taking up and resisting power can be realised. }\end{array}$ \\
\hline $\begin{array}{l}\text { A clear definition of } \\
\text { gender and sexuality, } \\
\text { and their differences, }\end{array}$ & $\begin{array}{l}\text { This is particularly important if the people in critical literacy classrooms } \\
\text { are to address controversial relations of power and identity such as those } \\
\text { related to gender and sexual diversity. For example, in South Africa the }\end{array}$ \\
\hline
\end{tabular}


to appear early on in the article

\section{Addition of author's} identity in methods section belief that homosexuality is unAfrican still persists in everyday discourses (Bhana, 2013; Jagessar \& Msibi, 2015) and affects how both hegemonic and marginalised ways of doing gender and sexuality are policed. How, then, when issues are naturalised in ways of speaking, thinking, doing and believing (Gee, 2008) do teachers and students explore them in constructive and critical ways? This is particularly pertinent where gender performance and sexual identity are conventionally conflated (Butler, 1993 and 2006) and used to justify heterosexism, bullying, and violence (from the symbolic to the physical). Therefore, I propose the need for critical literacy classrooms to explore power in relation to self: how does one position oneself in relation to privilege and subordination in the process of reimagining society and social justice?

In this study and the course that it investigates, I draw on conceptions of gender as a social practice, the performance of which is socio-culturally situated (Butler, 2006), as well as notions of sexual identity as an invisible difference that is intrinsically connected to issues of personal and social power (Butler, 2006). Reading and writing identity, then, serve as critical literacy practices where identity construction and performance can be interrogated through critical reflection.

While I am very interested in this comment and understand where it might come from, I chose to leave this information about myself out of this particular article. In a previous publication [Govender, N. N. (2017). The Pedagogy of 'Coming Out': Teacher Identity in a Critical Literacy Course. South African Review of Sociology, 48(1), 19-41.] I engaged with my own identity in relation to the course and the broader project.

I would be happy to take guidance from the editor regarding this.

Table 1 to be revised or removed.

I have opted to keep the table for two main reasons: One, revising the table into prose format would compromise my word count which is already quite high. Two, I agree that the table is not, on its own, highly valuable to the article and the overall discussion. However, it does contribute toward providing the reader a fuller picture of the data collected and the themes that emerged. Therefore, in relation to the analytical discussion, I believe the table is necessary for the reader to develop a better understanding of how my analysis sits within the wider data set.

Ritchie (2010) in-text $\quad$ Full-stop has been added.

citation - add fullstop.

\section{Revision One: Major revisions}

Reviewer comment/ $\quad$ Revised wording

change item

Revise title to suit aim

Critical Literacy \& Critically Reflective Writing: Navigating Gender \& Sexual Diversity 
Literature review to include

- recent sources,

- $\quad$ sources relevant to reflective writing, teacher education and gender and sexual diversity
The following sources have been integrated into the article. These sources aim to 1) increase relevance to the fields of critical literacy, reflective writing, and research on gender and sexual diversity in education more specifically. It also aims to make this article's context of study, South Africa, more explicit by referring to more contextually relevant literature.

Banegas, D. L., Jacovkis, L. G. \& Romiti, A. (2019). A Gender Perspective in Initial English Language Teacher Education: An Argentinian Experience. Sexuality \& Culture. Springer. https:/doi.org/10.1007/s12119-019-09604-8

Barney, K., \& Mackinlay, E. (2010). Creating rainbows from words and transforming understandings: Enhancing student learning through reflective writing in an Aboriginal music course. Teaching in Higher Education, 15(2), 161-173.

Carrington, S., \& Selva, G. (2010). Critical social theory and transformative learning: Evidence in pre-service teachers' servicelearning reflection logs. Higher Education Research \& Development, 29(1), 45-57.

Fairclough, N. (2001). Language \& Power. Second Edition. Longman: London

Francis, D. (2012). Teacher Positioning on the Teaching of Sexual Diversity in South African Schools. Culture, Health \& Sexuality, 14(6), 597-611.

Francis, D. (2017). Homophobia \& Sexuality Diversity in South African Schools: A Review. Journal of LGBT Youth, 14(4), 359-379.

Francis, D. \& Reygan, F. (2016). 'Let's see if it won't go away by itself': LGBT Microaggressions among Teachers in South Africa. Education as Change, 20(3), 180-201.

Gee, J. P. (2008). Social Linguistics \& Literacies. Routledge: London \& New York.

Govender, N. N. (2018). Deconstructing Heteronormativity \& Hegemonic Gender Orders through Critical Literacy \& Materials Design: A Case in a South African School of Education. In E. Walton \& R. Osman (eds.) Teacher Education for Diversity: Conversations from the Global South. Routledge: London \& New York. P. 36-52.

Govender, N. N. (2019). Negotiating Gender \& Sexual Diversity in English Language Teaching: 'Critical'-Orientated Educational Materials Designed by Pre-Service English Teachers at a South African University. In E. López-Gopar (ed.) International Perspectives on Critical Pedagogies in English Language Teaching. Palgrave Macmillan: Cham, Switzerland. P. 125-149. 
Janks, H., Rogers, R. \& O’Daniels, K. (2017). Language \& Power in the Classroom. In T. L. McCarty \& S. May (eds.) Language Policy \& Political Issues in Education. Springer: New York. P. 185-197.

Kalantzis, M., \& Cope, B. (2008). New learning: Elements of a science of education. Cambridge: Cambridge University Press.

Kumashiro, K. (2002). Troubling Education: Queer Activism and Antioppressive Pedagogy. Routledge Falmer: New York and London.

Liu, K. (2015). Critical Reflection as a Framework for Transformative Learning in Teacher Education. Educational Review, 67(2), 135-157.

Lock Swarr, A. (2009). "Stabane", Intersexuality, \& Same-Sex Relationships in South Africa. Feminist Studies, 35(3), 524-548.

López-Gopar, E. (ed.) (2019). International Perspectives on Critical Pedagogies in English Language Teaching. Palgrave Macmillan: Cham, Switzerland.

Mayeza, E. (2017). 'Girls don't play soccer': Children Policing Gender on the Playground in a Township Primary School in South Africa. Gender \& Education, 29(4), 476-494.

Morgan, R., Marais, C. and Wellbeloved, J. R. (eds.) (2009). Trans: Transgender Life Stories from South Africa. GALA: South Africa.

New London Group. (1996). A Pedagogy of Multiliteracies: Designing Social Futures. Harvard Educational Review, 66, 60-92.

Ovens, A., \& Tinning, R. (2009). Reflection as situated practice: A memory-work study of lived experience in teacher education. Teaching and Teacher Education, 25(8), 1125-1131.

Pennell, S. M. (2019). Moments of Active Reflection: Eddies. In S. M. Pennell. Queering Critical Literacy \& Numeracy for Social Justice: Navigating the Course. Palgrave Macmillan: Cham. P. 73-88.

Reygan, F. (2019). Sexual \& Gender Diversity in Schools: Belonging, In/Exclusion \& the African Child. Perspectives in Education, 36(2), 90102.

Ritchie, J. (2010). How Do You Say "Come Out of the Closet" in Arabic? Queer Activism and the Politics of visibility in Israel-Palestine. In GLQ, 16(4), 557-575.

Ryan, M. \& Ryan, M. (2013). Theorising a Model for Teaching \& Assessing Reflective Learning in Higher Education. Higher Education Research \& Development, 32(2), 244-257.

Vittoria, P. (2018). Critical Education in Paolo Freire: Educational Action for Social Transformation. Journal of Phenomenology \& Education, 22(51), 37-44.

The section of data analysis has been revised to help clarify how CDA was used to identify patterns in the data, interpret the patterns and then 
place these meanings into socio-cultural context (i.e. exploring explanatory power of meaning).

Furthermore, sources on CDA were also used throughout the data analysis to help pin my interpretations and explanations into the model more securely and explicitly.

The methodology section was revised to increase clarity of purpose of the study, as well as the processes followed in the collection and analysis of the data set.

The data presented and analysed here reveals three major themes: (1) gender as a social practice, (2) gender as intersectional, and (3) critical internal contradictions. The discussion of themes 1 and 2 outline the patterned meanings and implications in students' writing, while theme 3 presents an analysis of two particular examples of writing that engage with sexual identity. In each case, I draw on the data to evidence the themes and use Fairclough's (2001) model for critical discourse analysis to explore how students' reflective writing illustrates their positions in relation to the course content (Ryan \& Ryan, 2013) as well as consider what their writing reveals about learning through a critical literacy approach.

The literature review was streamlined to allow for increased discussion space in the discussion and conclusion of the article:

1. A more detailed account of the critical literacy course is provided in relation to structure and content covered.

2. Reference to recent literature on reflective writing, critical literacy and gender and sexual diversity in South Africa was used to pin the discussion to relevant fields and contexts.

3. The discussion attempted to engage more explicitly with the proposed implications for teaching and research.

4. References to Fairclough were made to create a clearer link between meaning and processes of analysis.

5. Recommendations are situated in recent literature on reflective writing for English language and (critical) literacy classrooms. 


\title{
Critical Literacy \& Critically Reflective Writing: Navigating Gender \& Sexual Diversity
}

\begin{abstract}
In this article, I draw on Janks' territory beyond reason as well as literature on (critically) reflective writing to explore how a space for personal, affective writing in the classroom might enable teachers, students and learners to 1) come to terms with gender as a social practice, 2) locate themselves in the relations of power, marginalisation and subversion being explored, and 3) negotiate the internal contradictions that come with personal and social transformation. The author presents and unpacks how 2nd-year undergraduate Bachelor of Education (B.Ed.) students at a prominent university in Johannesburg, South Africa, unpacked issues of gender and sexual diversity in a critical literacy course. This article focuses on students' completion of a reflective writing task but is situated in a broader study on critical literacy and gender and sexual diversity. The findings suggest the need for sustained critically reflective writing in the classroom and continued research in critical literacy as both a rationalist and affective project. Furthermore, the findings suggest ways in which critically reflective writing was used to create a space where students could place themselves into the content and relations of power being studied and identify and unpack the ways in which discourses of power have informed their own identities over time, with the intent to develop the capacity to position themselves in more socially conscious ways. This study therefore illustrates only a fraction of how students might use reflective writing to come to terms with controversial topics, place themselves in the systems of power, marginalisation or subversion being explored, and negotiate the internal contradictions of transformation. However, the data also suggests that there is potential for this practice to have a greater role in classroom practice, a deeper effect on learners' understanding of self and society, and further research on the impact of critical reflection in the classroom.
\end{abstract}

\section{Key words:}

Critical literacy, reflective writing, gender and sexual diversity 


\section{Introduction}

Where identification promises the fulfilment of desire, reason cannot compete. (Janks, 2002, 10).

Janks' (2002) words in the article Critical Literacy: Beyond Reason serves as the basis for the argument I make here: that the role of self (in relation to identity, place, politics and desire) is, for its part, a vital component for critical literacy practice. While Janks (2002) explores this in relation to textual analysis and students' investment in particular social issues, I aim to consider how space for students' personal reflections might enable them to make the critical turn of placing themselves in, around or outside the relations of power explored in critical literacy classrooms.

This is particularly important if the people in critical literacy classrooms are to address controversial relations of power and identity such as those related to gender and sexual diversity. For example, in South Africa the belief that homosexuality is unAfrican still persists in everyday discourses (Bhana, 2013; Jagessar \& Msibi, 2015) and affects how both hegemonic and marginalised ways of doing gender and sexuality are policed. How, then, when issues are naturalised in ways of speaking, thinking, doing and believing (Gee, 2008) do teachers and students explore them in constructive and critical ways? This is particularly pertinent where gender performance and sexual identity are conventionally conflated (Butler, 1993 and 2006) and used to justify heterosexism, bullying, and violence (from the symbolic to the physical). Therefore, I propose the need for critical literacy classrooms to explore power in relation to self: how does one position oneself in relation to privilege and subordination in the process of reimagining society and social justice?

In this study and the course that it investigates, I draw on conceptions of gender as a social practice, the performance of which is socio-culturally situated (Butler, 2006), as well as notions of sexual identity as an invisible difference that is intrinsically connected to issues of personal and social power (Butler, 2006). Reading and writing identity, then, serve as critical literacy practices where identity construction and performance can be interrogated through critical reflection.

To explore this, I present and unpack how $2^{\text {nd }}$-year undergraduate Bachelor of Education (B.Ed.) students at a prominent university in Johannesburg, South Africa, reflected on their own experiences with gender and sexual diversity in writing. The students discussed here attended a module on critical literacy as part of their English (sub)major. The module was the site of a broader research project that explored critical literacy as a means to engage with gender and sexual diversity in South African English classrooms (Govender, 2017, 2018 
$\& 2019)$. The reflective writing activity constituted one small part of that pedagogy where students constructed short, autobiographical vignettes. An analysis of these vignettes offers possibilities for critically reflective writing to be used as a space where students identify and unpack how discourses of power have positioned their own identities and develop the capacity to position themselves in more socially conscious ways.

\section{Reason, Desire \& Reflective Writing in the Critical Literacy Classroom}

Despite critical literacy's socially transformative agenda, it is entirely possible that "students could produce the required deconstructive reading of the text... without any change in either their aspirations or their practices" (Janks, 2002, 10). As such, there is always the risk that power can be addressed in only superficial ways in the classroom, despite the intentions of the teacher. Janks (2002) found that it was not easy to predict which texts for analysis students would react to and in what ways, because of the "territory beyond reason" (Janks, 2002, 9).

This 'territory' includes the politics of desire and identification where a purely rationalist approach to teaching about and through social issues must consider students' emotional connections to the social issue itself. That is, it is perhaps easier for students who identify with positions of resistance if they themselves have been marginalised in some way. On the other hand, students who identify with normativity may struggle - or find it impossible - to see how that norm marginalises others, or how they have been positioned by that norm. Zembylas $(2008,65)$ recognises this ability to see one's own privilege as necessary for critically reflexive work that is considerate of emotional attachment and so consists in the ability to question emotionally charged, cherished beliefs exposing how privileged positions and comfort zones inform the ways in which one recognises what and how he or she has been taught to see or act (or not see/act), and empowering different ways of being with or for the other.

Perhaps it is also more complex than this: students who occupy a marginalised position in relation to socio-economic circumstance may see their plight as being more significant over those who suffer discrimination and subordination due to their gender and/or sexual identities. At any given point, one may occupy a position of privilege, marginality, or invisibility depending on the identity category or social issue being highlighted.

In situations where issues of gender and sexual diversity are concerned, emotional responses and attachments to ideologies can enable or inhibit productive ways of imagining 
more socially just futures. Ellsworth (discussed in McKinney, 2008) suggests that, in such cases and perhaps for all critical literacy practice, an assumption that students will automatically be taken up by critical practice and transform themselves and society "ignores the way in which people have investments in particular social positions and discourses, and that these kinds of investments are not lightly given up" (McKinney, 2008, 100). Perhaps, then, both positions of privilege and marginalisation, across a spectrum of identities and social issues, needs to be interrogated.

As one option, reflective writing may provide a space for students to explore a social issue in relation to their own histories, geographies, religions/traditions, ideologies, and life experiences. In this sense, reflection is "active, persistent, and careful consideration of any belief or supposed form of knowledge in the light of the grounds that support it and the further conclusions to which it tends" (Dewey, 1933, 9), in conjunction with a Freirean understanding that "Liberation is a praxis: the action and reflection of men and women upon their world in order to transform it" (Freire, 1970, 52). Here, according to Freire (1970), humility in recognising one's own place in the socio-political orders of oppression is fundamental to transformation. By looking at critical incidents and experiences (as texts) in relation to issues of power, teachers and students might interrogate the ways in which social and political power influence the everyday construction of individual identities, how individuals take up or resist hegemonic orders and the ways in which individuals occupy positions of privilege and subordination at different times and in different spaces.

In the classroom, 'authentic reflection' trusts that students and teachers, over time, can make connections between systems of power and themselves before endeavouring to dismantle those hegemonies, de/reconstruct their own subject positions, and explore ways to realise imagined change (Vittoria, 2018; Ryan \& Ryan, 2013; Janks, Rogers \& O’Daniels, 2017). By asking students to engage with personal critical incidents from everyday experiences, they might tap into the ways in which they have been positioned willingly and unwillingly, knowingly or unknowingly, by the dominant discourses of their time.

Confronting one's own privilege and subordination, as well as the privileging or subordination of others, is not an easy task. Ryan and Ryan (2018) propose a useful way of thinking about how to collate the various approaches of reflectivity into a model for doing and measuring critical reflection. It therefore becomes useful to quote at length their explanation:

Such reflection is underpinned by a transformative approach to learning that sees the pedagogical process as one of knowledge transformation rather than 
knowledge transmission (Kalantzis \& Cope, 2008; Leonardo, 2004). The learner is an active participant in improving learning and professional practice. Critical social theory underpins this transformative approach to reflection [and is] concerned with emancipation; however it also engages in a language of transcendence, whereby critique serves to cultivate students' abilities to question, deconstruct and reconstruct their own practices and imagine an alternative reality (Giroux, 1988; Kincheloe, 2003). When students are provided with opportunities to examine and reflect upon their beliefs, philosophies and practices, they are more likely to see themselves as active change agents and lifelong learners within their professions (Mezirow, 2006) (original parenthesis: Ryan \& Ryan, 2018, 246)

Writing, interspersed throughout other classroom practices, might help to create a continuous safe space for students to tackle issues of power and society in a personal way. Emotion, in this space, would be a resource rather than a hinderance to criticality. Furthermore, ongoing reflective writing can be challenged: 1) using Kalantzis and Cope's (2008) taxonomy of experiencing, conceptualising, analysing and applying to measure critical engagement, and 2) moving from simulated to real scenarios to measure development in reflective practice (Ryan \& Ryan, 2018).

Critical reflection in this sense is about making the commonsense strange (Janks, 2010; Freire, 1970; Freire \& Macedo, 1987): across personal, public and political spheres. By doing so, students can attempt to re-evaluate self and society, imagining transformation as both personal and Political (Janks, 2010).

\section{Methodology}

The data presented here was collected during the implementations of a critical literacy module for second-year B.Ed. students at a university in Johannesburg, South Africa. This course explored critical literacy by unpacking the relationship between language, literacy and power for secondary school classrooms using gender and sexual diversity as the example social issue.

\section{The module}

The module comprised of 9 seminars and worked from a workbook that I had designed which included a range of topics and activities for engaging with gender and sexual diversity in secondary English language and literacy classrooms. Namely, these topics included 
Language, Policing \& Subversion, (Re)Design, and Social Impact (Govender, 2018): 1. Language, involves students discussing how language can be used to name people and activities in ways that (de)legitimise particular identities and practices across modes and media. 2. Policing \& Subversion explored a variety of texts that represented 'alternative' ways of being or doing sex, gender and sexuality, as well as an analysis of the kinds of responses that these representations received. This section included navigating representations of both hegemonic and subversive gender and sexual identities and practices as a means to unpack how powerful discourses emerge and how resistance takes form. 3. (Re)Design drew on New London Group's (1996) concept of design as transformative practice. Reflecting on the subversive texts that students had analysed, strategies for reconstructing representations of gender and sexual diversity in classrooms were explored. Finally, 4. Social Impact introduced students to ways of thinking about the social effects that their pedagogical decisions in the classroom might have in maintaining, reproducing or challenging social norms. A deeper analysis of the student teachers' responses to the course content and up-take of critical literacy practice can be read found in Lopez-Gopar's (2019) International Perspectives on Critical Pedagogies in ELT.

In the broader study, a qualitative mixed methods approach was adopted for the collection and analysis of data including field notes of the classes I taught, critically reflexive accounts of the design process of the workbook and other materials or resources used for teaching the module (see Govender, 2018), a 'research journal' in which I recorded my own responses and reflections on interactions with students throughout the study (see Govender, 2017), notebooks wherein students who attended the module completed activities both in and out of the lecture theatre, students' evaluations of the module content and presentation, as well as the final assessment task where students produced their own critical literacy materials (see Govender, 2019).

What sets this apart from other research in Initial Teacher Education (ITE) is the compulsory nature of the module - all students registered for English II were required to attend the critical literacy module as part of their degree. While participation in the research was voluntary, the module itself was not an elective. This meant that the cohort of students were diverse and the selection of participants in the research project included, along a spectrum of investments (Darvin \& Norton, 2015), students who were interested in gender and sexual diversity and those students who were explicitly uncomfortable with the topic. 
For this article, I draw on the data collected from only one section on Language \& Policing (see above). The data set from this section includes the reflective writing produced by 6 students, as a voluntary homework task. As this task was not formally assessed and the module did not require any participants (lecturer/researcher or students) to claim their own gendered or sexual identities in any form, students could choose to complete in the task or not. Ethical approval was obtained for the study and participants consented to the use of the data for research.

In the lecture, Robert Hamblin's (in Morgan, Marais \& Wellbeloved, 2009) autobiographical poem about being a transgender man was analysed and discussed. Using this as a springboard, students were asked to reflect on a moment when they think they were socialised into a particular gender order.

The vignettes were analysed using Fairclough's (2001) model of Critical Discourse Analysis (CDA), firstly, to reveal patterns across the data set (themes 1 and 2), and secondly to uncover how students reflected on their own identities in relation to diversity (theme 3 ). The critical analysis spans Fairclough's (2001) domains of description, interpretation and explanation in order to draw meaning from the written data and explore the socio-cultural significance of those meanings.

\section{Data presentation \& analysis}

The data presented and analysed here reveals three major themes: (1) gender as a social practice, (2) gender as intersectional, and (3) critical internal contradictions. The discussion of themes 1 and 2 outline the patterned meanings and implications in students' writing, while theme 3 presents an analysis of two particular examples of writing that engage with sexual identity. In each case, I draw on the data to evidence the themes and use Fairclough's (2001) model for critical discourse analysis to explore how students' reflective writing illustrates their positions in relation to the course content (Ryan \& Ryan, 2013) as well as consider what their writing reveals about learning through a critical literacy approach.

\section{(1) Gender as a social practice}

While students' written reflections on gender policing in their own lives varied in length and content, they all presented a definite theme that gender is a social practice. This mirrors Connell's (1995) work on hegemonic masculinities and other studies that see gender practice and performance as socio-culturally situated and regulated (Francis, 2017; Paechter, 1998 \& 2006; Butler, 1993 \& 2006; Connell, 1995 \& 2000; Gevisser \& Cameron, 1994; Luyt, 2012; 
Rich, 1993; Tucker, 2009). Recognition of this is significant because it contradicts the commonsense sex-gender-sexuality relation as a necessary one (Butler, 2006).

The following extracts are quoted directly from each of the written reflections, and refer explicitly to gender being a process of socialisation:

"I grew up and was socialised to respond and maintain characteristics of a girl" (A12.5);

"I became socialised into a gender category through religion" (A01.5);

"I was raised to be a respectful young lady. I had to behave like a girl..." (A03.5);

“'Proper' gender is falling into a category of either male + masculine or female + feminine created by societies" (A02.6);

"When you grow up, you are also obliged to attend an initiation school for two months being taught on how to behave like a man" (B01.10); and

"In my religion Islam teaches us ladies to be modest + conservative in our dressing" (A14.4).

From the extracts above, it is easy to see how these students were able to locate some of the ways that they learnt, or acquired, particular gender performances. From the role of religion and initiation schools to families, the extracts exemplify a kind of positioning of oneself in the theory. Students began to engage not only with memory as meaning, but also as situated in particular socio-cultural conditions (Fairclough, 2001). Not only does this suggest that identification (locating oneself in the content of the classroom) takes place but also application (using the content of the classroom to reconsider one's own experiences) as part of the (re)learning process in a transformative pedagogy. Students located the course content, themselves, and the embedded ideologies that inform their experiences as "real, socially operative [sites] of institutional and societal processes of struggle" (Fairclough, 2001, 117) and this is evident in the way they position their experiences with gender in processes of being "taught", as well as being "socialised" and "raised" into gender roles. In these utterances alone is the notion of gender order as systemic, and individual agency as minimal. Both the processes and sites of struggle also matter. For example, the differences between how a particular kind of masculinity was learnt by the participant who wrote about attending a Southern African initiation school may resonate and differ in many ways from the participant whose affiliation with Islam created a space for learning 'proper' femininities. The particular experiences and conditions of gender identity construction (that is, how the rules for doing gender were learnt) suggest that the personal spaces of participants' lives could be highlighted as significant sites of critical reflection. Over time, it is suggested that such critical reflection must become more rigorous (Ryan \& Ryan, 2013) in order to be, one, 
more cognitively challenging for these students as future teachers and reflective practitioners, and two, to enable a deeper sense of consciousness of the relationship between self, word, action and social effect (Vittoria, 2018). For instance, evaluating how students seem to place themselves in object-position (as in Halliday's, 1985, done-tos) in their own writing might reveal more about how they perceive their own agency.

The application, negotiation and exploration of the content in relation to one's own lived experiences "brings high level academic understandings together with students' lived experience and provides them with the intellectual means for complex analyses" (Comber, $2015,365)$. The reflective writing space is a fluid one and so the meanings that students produce here is not yet fixed, but perhaps allows students to anchor conceptual knowledge in their known realities in the process of making meaning (Smagorinsky, 2001).

This is particularly significant when handling content that is sensitive or controversial to so many. In trying to conceptualise gender as a social practice, established understandings of gender conflated with biological sex need to be deconstructed, unlearned and renegotiated with nondominant perspectives (Govender, 2019). This is not an easy task. Merely introducing texts with same-sex couples or nonconforming gender and sexual identities does not automatically ensure that students, teachers and school curriculums are transformed (Kumashiro, 2000). In contexts where hegemonic gender order is still heterosexist and cisnormative, finding ways for students to negotiate meaning and come to terms with diverse perspectives is necessary to foster a constructive turn toward socially just pedagogies.

But, gender does not exist on its own. As illustrated in students' vignettes, what it means to learn, acquire and become a gender identity is deeply connected with the place, time, culture, language, age, among others, that situate each individual and their actual or imagined communities.

\section{(2) Gender as intersectional}

In the same way that Gevisser and Cameron (1994) emphasise that there is no one gay identity in South Africa, there is also no single, essentialised identity for gender, race, culture/tradition, religion, and so on, (Connell, 1995; Milani, 2013; Ritchie, 2010). The students in this study draw on a myriad of experiences that inform and are informed by their own gendered identities. The following table briefly outlines these intersections in students' writing:

Table 1: Intersections with Gender 
From home to broader society, to the recognition that gender and sexuality are issues around the "real world" (A14.4), it is their everyday spaces and interactions that these students come to know and live gendered identities. That is, whether these students consciously recognise it or not "[s]pace can be filled with all kinds of social, cultural, epistemic, and affective attributes. [That] then becomes 'place', a particular space in which senses of belonging, property rights, and authority can be projected" (Blommaert, 2005, 222 in Milani, 2013, 206207). Here, belonging, or not belonging, and the relations of power that exist within these spaces seemingly inform how students have considered gender and sexuality.

From the figures in Table 1, the local and lived spaces of daily life are the ones most prominent for being socialised into hegemonic gender order. It is the life-long, cumulative engagement with these interactions, in everyday spaces, that ways of being, acting, speaking, and understanding are subjected to relationships of power and attached to ideas about morality. It is also within many of these spaces that gender intersects with the other attributes of identity, like race, religion, language, or sexuality.

In this particular data set, only one reference is made to ethnicity, "I am an Indian", with a corresponding declaration of religious identity: "I am a Muslim. I am an Indian". After these statements, this student focuses on religious identity, social spaces and gender construction. This can be seen in the way that the student has written about their understanding of the male-female binary and its associated gender roles:

“...in our culture men are given the status of superiority... Breadwinners, Money makers. Women are looked at as housewives + mommies. It's questioned when mom's rake in the money" (extract from A14.4).

It is uncertain whether 'culture' here is used to refer to Islamic culture, the Islamic religion or an Indian culture, however it is through all of these social institutions that the sexes and their 'appropriate' gender roles and performances are constructed. Heteronormative cisgender roles are rationalised as intrinsic to 'culture'. Religion and culture/tradition are regularly foregrounded as institutions that regulate gender construction and performance in this data set. In each of the vignettes, there is some reference to at least one of these social institutions. Each reference to religion, culture or tradition, however, is still compounded by an intersection with age and gendered social roles:

"Kneeling was expected of a girl in my culture especially when serving adults" (A12.5);

"Due to my culture and religion, once you've become matured, there are certain things that become compulsory to do on a daily basis and the manner in which it is done is different for males and females" (A01.5). 
Or it was compounded by an intersection with language, where language reinforces sexed, gendered or sexualised difference as intrinsic to identity:

"[I]n my culture there are many words that have separate words for male $\&$ female. e.g. in the Arabic language the "Hu" at the end of an object is for males and the letter "Haa" is for females" (parenthesis added: A01.5);

"'Because you are a girl'. One phrase I have heard and hated my entire life" (A02.6). And, in some cases it is even compounded by painful intersections with the conflict between family expectations and personal aspiration:

After my mother died, my step dad expected me to cook and clean whilst my studies were sidelined. I will never hate anything as much as I hate this period of my life where I have to cook, clean and be subservient to a man because I am a young woman (extract from A02.6).

These institutionalised normative gender roles seem to bind almost all intersections of gender with other identity categories and suggests that these students' experiences resonate with research on gender and sexual diversity in South Africa (Lock Swarr, 2009; Bhana, 2013 Mayeza, 2017; Francis, 2017; Francis \& Reygan, 2016; and so on). If such normativity persists in the lives of student teachers, surely it becomes necessary for (teacher) education at large to intervene? Critical reflective writing, as one practice in a broader critical literacy approach, may provide a way for teachers and learners to navigate identity, power and diversity in meaningful and constructive ways, where "processes of self-reflection in teacher education require teachers to interrogate their experiences of marginalisation and privilege" (Reygan, 2019) by asking critical questions (Janks, 2010) of themselves.

In each case, these students have engaged with a critical reflection of their own lives and the social structures that have come to influence their identities. Perhaps, then, part of taking the critical turn means consciously exploring how one has been positioned by their sociocultural context (Fairclough, 2001), making texts of themselves. Only then can one begin to resist or choose to take up the positions available in that context, using literacy "to raise consciousness (conscientizacao) regarding the actual reality of oppression" (Vittoria, 2018, 38).

\section{(3) Reflecting on Sexuality \& Sexual Diversity}

Work on the pedagogies that enable students and teachers to explore, understand and negotiate issues of self and power through language has become especially important for understanding how education can work in relation to issues of sexuality. This is where 
nondominant sexualities are still avoided because they seem too controversial to discuss with school-going students or where teachers feel ill-equipped to engage with such topics (Francis \& Reygan, 2016; Reygan, 2019; Francis, 2012).

In this section, I discuss two examples: students A and B. While student A identifies as 'unsure' about their sexual identity, student B implies a heterosexual identity. By discussing these two examples, it becomes evident that a wide spectrum of viewpoints and experiences can occupy a single learning space, reinforcing critically reflective writing as a way for individuals to process their relationship with curricular content and diversity.

For student A, a queer understanding of sexuality is taken: Being 'unsure' about sexual identity suggests that sexuality itself is recognised as fluid. Furthermore, this student states that their sexuality is assumed to be heterosexual, recognising the heteronormative context they find themselves in. Their expression can be read as a resistance to such heteronormativity where the student was able to name their experience without conflict (Pennell, 2019). This practice of naming and renaming oneself and the world signifies a potential for increased agency (Freire, 1970) where learners and teachers who occupy gender and sexual diversity can claim their experiences and critically reflect on them in a move toward personal and social transformation.

However, this was not always the case. While critical literacy may open spaces for resistance, it may also be a space for contradiction. Student B who implicitly self-identifies as a heterosexual also positions themselves as both conservative, because of their Islamic and Indian identities, and liberal by aligning themselves to the idea of freedom. In this sense, critical literacy helped reveal the internal conflicts and contradictions that come with transformation.

Initially, an inclusive, liberal discourse, was used to validate sexual diversity:

"In the real world there is a variety of sexuality - Gays, lesbians, bisexuals"

(extract from A14.4).

However, this was followed by their personal feelings toward sexual diversity::

"Do I believe in all? Maybe not... Actually no!" (A14.4).

There is recognition that sexual diversity exists, while there is disagreement that nonheterosexual identities are 'right'. This may be an example of hyperinclusivity that masks internal resistance to types of diversity (Govender, 2019). However, this student thereafter reverts to the liberal discourses of freedom which is only problematic because their use of 'freedom' is expressed as 'freedom of choice': 
"The world is changing so is society. People are free \& open to choose his/her sexuality" (A14.4); and

"The world is free. Sexuality is your choice!" (A14.4).

Again, the stereotype that non-heterosexual identities are a 'lifestyle choice' is maintained. This reproduces the discourses of heteronormativity despite its appearance of being inclusive through the use of words such as "free", "open", or "choice" juxtaposed against the illegitimating declaration that not "believe[ing] in all" is still present. For the critical literacy classroom, this way of speaking about difference and the kind of hedging used is a useful text for deconstructing the nuances of power and language.

Looking at the policing of gender in relation to the lives of students has thus been helpful for considering students' own positions in relation to gender and sexual diversity, whether they themselves fit typically normative or nonconforming identities. A prolonged practice of critical reflective writing is therefore recommended to further deepen both personal and social consciousness; a fitting practice for the critical literacy classroom.

\section{Conclusion}

If critical literacy is to equip teachers with the capacity to confront and transform discourses in and out of schools, then practices that purposefully engage with uncomfortable positions is needed. As such education beyond rationality or formulaic reasoning is necessary when using the classroom as a medium for addressing social issues that are often bound to emotive responses. Issues related to gender and sexual diversity, for instance, can tug at often hegemonic lines of reasoning that are informed by faith, heterosexist normativity, patriarchal traditions, a history of symbolic and real violence, as well as the very systems of government or social order under which people live. Even in the seemingly small declarations of "no!" or the positioning of oneself as a victim of systemic gender order through word-order and sentence structure, space for taking up and resisting power can be realised. In situations such as these, it is very easy for social justice work to be read as a threat to normativity rather than a move toward equity.

Existing resources on critically reflective writing are vital for imagining what this prolonged practice might look like in classrooms. As discussed, Ryan and Ryan (2013) provide a framework for considering how critical reflectivity can be practised and measured in higher education. For teacher education that seeks to equip new and developing teachers with the capacity to confront issues of diversity, especially through a critical literacy project, this criteria-based and developmental framework could prove useful. Numerous other sources 
are cited in this work as well (including Barney \& Mackinlay, 2010; Carrington \& Selva, 2010; and Ovens \& Tinning, 2009). Similarly, Liu (2015) recommends that not only should the what of reflective practice be considered, but also the how and the why. By doing so, student teachers might begin to ask questions about how their reflections become critical or limiting, as well as why their reflections may or may not have an impact on their own teaching and learning. While Liu (2015) does not deal with any specific social issue, the framework serves as a useful base from which to consider ways of doing critical reflection and how this might be implemented through continuous writing practice. Furthermore, Pennell's (2019) extended metaphor of kayaking for thinking about literacy and numeracy teaching/learning is another example of anti-oppressive pedagogies. Pennell (2019) reiterates, as eddies in a river, the need for measured and continued practices of reflection which could be anchored in practices of writing.

Specific research in gender and sexual diversity in South Africa also suggests the need to include the affective when addressing issues that are deemed contentious for students and teachers (Reygan, 2019; Francis, 2017). Similarly, Banegas, Jacovkis and Romiti (2019) find a place for reflective practice in arguing for the relevance of gender and sexual diversity in TESOL initial English language teacher education in Argentina. Perhaps there is scope for further, long-term research in the role of critically reflective writing, critical literacy classrooms and the territory beyond reason across social issues and educational contexts.

Throughout this article, I have used critically reflective writing to argue for the inclusion of personal, emotive and authentic engagement with social issues as part of everyday classroom practice for critical literacy teachers and learners. The data presented here is limited and illustrates only a fraction of how students might use reflective writing to come to terms with controversial topics, place themselves in and out of systems of power, marginalisation, or subversion, and negotiate the internal contradictions of transformation. However, this data also suggests that there is potential for this practice to have a greater role in classroom practice, a deeper effect on learners' understanding of self and society, and further research on the impact of critically reflective writing in the classroom. Perhaps a sustained practice of critically reflective writing is what is needed, as well as processes of self and peer evaluations that put that writing up for critical analysis. 


\section{References}

Banegas, D. L., Jacovkis, L. G. \& Romiti, A. (2019). A Gender Perspective in Initial English Language Teacher Education: An Argentinian Experience. Sexuality \& Culture. Springer. https:/doi.org/10.1007/s12119-019-09604-8

Barney, K., \& Mackinlay, E. (2010). Creating rainbows from words and transforming understandings: Enhancing student learning through reflective writing in an Aboriginal music course. Teaching in Higher Education, 15(2), 161-173.

Bhana, D. (2013). Parental Views of Morality \& Sexuality \& the Implications for South African Moral Education. Journal of Moral Education, 42(1), 114-128.

Butler, J. (1993). Imitation \& Gender Insubordination. In H. Abelove, M. Aina Barale \& D. M. Halperin (eds.) The Lesbian \& Gay Studies Reader. Routledge: New York \& London.

Butler, J. (2006). Gender Trouble. Routledge: New York.

Carrington, S., \& Selva, G. (2010). Critical social theory and transformative learning: Evidence in pre-service teachers' service-learning reflection logs. Higher Education Research \& Development, 29(1), 45-57.

Comber, B. (2015). Critical Literacy \& Social Justice. Journal of Adolescent \& Adult Literacy, 58(5), 362-367.

Connell, R. W. (1995). Masculinities. Allen \& Unwin: Australia.

Connell, R. W. (2000). The Men \& the Boys. Allen \& Unwin: Australia.

Darvin, R. \& Norton, B. (2015). Identity \& a Model of Investment in Applied Linguistics. Annual Review of Applied Linguistics, 35(1), 36-56.

Dewey, J. (1933). How we think: A Restatement of the relation of Reflective Thinking to the Educative Process. D.C. Heath: Boston.

Fairclough, N. (2001). Language \& Power. Second Edition. Longman: London

Francis, D. (2012). Teacher Positioning on the Teaching of Sexual Diversity in South African Schools. Culture, Health \& Sexuality, 14(6), 597-611.

Francis, D. (2017). Homophobia \& Sexuality Diversity in South African Schools: A Review. Journal of LGBT Youth, 14(4), 359-379.

Francis, D. \& Reygan, F. (2016). 'Let's see if it won't go away by itself': LGBT Microaggressions among Teachers in South Africa. Education as Change, 20(3), 180201.

Freire, P. (1970). Pedagogy of the Oppressed. M. Bergman Ramos (trans. 1970). Continuum: New York. 
Freire, P. \& Macedo, D. (1987). Rethinking Literacy: A Dialogue. P. Freire \& D. Macedo (eds.) Literacy: Reading the Word \& the World. Bergin \& Garvey: New York.

Gee, J. P. (2008). Social Linguistics \& Literacies. Routledge: London \& New York.

Gevisser, M. \& Cameron, E. (1994). Defiant Desire. Ravan Press: Johannesburg, South Africa.

Govender, N. N. (2017). The Pedagogy of 'Coming Out': Teacher Identity in a Critical Literacy Course. South African Review of Sociology, 48(1), 19-41.

Govender, N. N. (2018). Deconstructing Heteronormativity \& Hegemonic Gender Orders through Critical Literacy \& Materials Design: A Case in a South African School of Education. In E. Walton \& R. Osman (eds.) Teacher Education for Diversity: Conversations from the Global South. Routledge: London \& New York. P. 36-52. Govender, N. N. (2019). Negotiating Gender \& Sexual Diversity in English Language Teaching: 'Critical'-Orientated Educational Materials Designed by Pre-Service English Teachers at a South African University. In E. López-Gopar (ed.) International Perspectives on Critical Pedagogies in English Language Teaching. Palgrave Macmillan: Cham, Switzerland. P. 125-149.

Halliday, M. A. K. (1985). An Introduction to Functional Grammar. London, New York, Melbourne \& Auckland: Edward Arnold.

Jagessar, V. \& Msibi, T. (2015). "It's not that bad": Homophobia in the Residences of a University in KwaZulu-Natal, Durban, South Africa. Agenda, 29(1), 63-73.

Janks, H. (2002). Critical Literacy: Beyond Reason. The Australian Educational Researcher, 29(1), 7-26.

Janks, H. (2010). Literacy \& Power. Routledge: New York \& London.

Janks, H., Rogers, R. \& O’Daniels, K. (2017). Language \& Power in the Classroom. In T. L. McCarty \& S. May (eds.) Language Policy \& Political Issues in Education. Springer: New York. P. 185-197.

Kalantzis, M., \& Cope, B. (2008). New learning: Elements of a science of education. Cambridge: Cambridge University Press.

Kumashiro, K. (2002). Troubling Education: Queer Activism and Antioppressive Pedagogy. Routledge Falmer: New York and London.

Liu, K. (2015). Critical Reflection as a Framework for Transformative Learning in Teacher Education. Educational Review, 67(2), 135-157.

Lock Swarr, A. (2009). "Stabane”, Intersexuality, \& Same-Sex Relationships in South Africa. Feminist Studies, 35(3), 524-548. 
López-Gopar, E. (ed.) (2019). International Perspectives on Critical Pedagogies in English Language Teaching. Palgrave Macmillan: Cham, Switzerland.

Luyt, R. (2012). Constructing Hegemonic Masculinities in South Africa: The Discourse \& Rhetoric of Heteronormativity. Gender \& Language, 6(1), 47-77.

Mayeza, E. (2017). 'Girls don't play soccer': Children Policing Gender on the Playground in a Township Primary School in South Africa. Gender \& Education, 29(4), 476-494.

McKinney, C. (2008). Uncomfortable Positionings: Critical Literacy \& Identity in a PostApartheid University Classroom. K. Cooper \& E. R. White (eds.) Critical Literacies in Action: Social Perspectives \& Teaching Practices. Sense Publishers: Rotterdam, Netherlands. P. 99-116.

Milani, T. M. (2013). Expanding the Queer Linguistic Scene: Multimodality, Space \& Sexuality at a South African University. Journal of Language \& Sexuality, 2(2), 206234.

Morgan, R., Marais, C. and Wellbeloved, J. R. (eds.) (2009). Trans: Transgender Life Stories from South Africa. GALA: South Africa.

New London Group. (1996). A Pedagogy of Multiliteracies: Designing Social Futures. Harvard Educational Review, 66, 60-92.

Ovens, A., \& Tinning, R. (2009). Reflection as situated practice: A memory-work study of lived experience in teacher education. Teaching and Teacher Education, 25(8), 11251131.

Paechter, C. (1998). Educating the Other: Gender, Power \& Schooling. Falmer Press: London, United Kingdom.

Paechter, C. (2006). Masculine Femininities/ Feminine Masculinities: Power, Identities \& Gender. Gender \& Education, 18(3), 235-263.

Pennell, S. M. (2019). Moments of Active Reflection: Eddies. In S. M. Pennell. Queering Critical Literacy \& Numeracy for Social Justice: Navigating the Course. Palgrave Macmillan: Cham. P. 73-88.

Reygan, F. (2019). Sexual \& Gender Diversity in Schools: Belonging, In/Exclusion \& the African Child. Perspectives in Education, 36(2), 90-102.

Rich, A. (1993). Compulsory Heterosexuality \& Lesbian Existence. In H. Abelove, M. Aina Barale \& D. M. Halperin (eds.) The Lesbian \& Gay Studies Reader. Routledge: New York \& London.

Ritchie, J. (2010). How Do You Say "Come Out of the Closet” in Arabic? Queer Activism and the Politics of visibility in Israel-Palestine. In $G L Q, 16(4), 557-575$. 
Ryan, M. \& Ryan, M. (2013). Theorising a Model for Teaching \& Assessing Reflective Learning in Higher Education. Higher Education Research \& Development, 32(2), 244-257.

Smagorinsky, P. (2001). If Meaning Is Constructed, What Is It Made From? Toward a Cultural Theory of Reading. Review of Educational Research, 71(1), 133-169.

Tucker, A. (2009). Queer Visibilities: Space, Identity \& Interaction in Cape Town. WileyBlackwell: Sussex, United Kingdom.

Vittoria, P. (2018). Critical Education in Paolo Freire: Educational Action for Social Transformation. Journal of Phenomenology \& Education, 22(51), 37-44.

Zembylas, M. (2008). Engaging with Issues of Cultural Diversity \& Discrimination through Critical Emotional Reflexivity in Online Learning. Adult Education Quarterly, 59(1), 61-82. 


\begin{tabular}{|l|l|l|}
\hline \multicolumn{2}{|l|}{ Gender intersecting with... } & No. of occurrences \\
\hline Race & 1 \\
\hline Sexuality & 2 \\
\hline Religion & 3 \\
\hline Culture or tradition & Childhood & 4 \\
\hline \multirow{3}{*}{ Age (5) } & Coming of age & 4 \\
\hline Class/ Socio-economic status & 1 \\
\hline \multirow{4}{*}{ Place (15) } & Home & 0 \\
\cline { 2 - 3 } & School & 4 \\
\cline { 2 - 3 } & Community & 4 \\
\cline { 2 - 3 } & “Society” & 3 \\
\cline { 2 - 3 } & World & 1 \\
\hline \multirow{2}{*}{ Role models (6) } & Family & 4 \\
\cline { 2 - 3 } & Community & 1 \\
\hline \multirow{2}{*}{ Language (4) } & Media & 1 \\
\cline { 2 - 3 } & Language use & 3 \\
\hline
\end{tabular}

Table 1: Intersections with Gender 